\title{
PENGARUH WISATA TAMAN ASRI TERHADAP PEREKONOMIAN MASYARAKAT YANG BERADA DI SEKITAR JALUR 8 JEMBATAN 3 KECAMATAN AIR SALEK KABUPATEN BANYUASIN
}

\author{
Mega Kusuma Putri ${ }^{1}$, Yunita ${ }^{2}$ \\ ${ }^{1,2}$ Pendidikan Geografi Universitas PGRI Palembang \\ ${ }^{1}$ Email : puteri.mega@ rocketmail.com
}

\begin{abstract}
The problem in this study is "Is there the Effect of Taman Asri Tourism on the Economy of Communities in the vicinity of Lane 8 Bridge 3 Air Salek District Banyuasin Regency? "The purpose in this study is to analyze the Effect of Taman Asri Tourism on the Economy of Communities around the Path 8 Bridge 3 Air Salek District Banyuasin Regency. This research method uses quantitative descriptive method. The population in this study is the community that lives around the beautiful garden consisting of 129 families, the sampling technique uses cluster sampling (Area Sampling). Data collection techniques in this study used a questionnaire with a gutman scale. The analysis used in this study used the t-test. The results of this research that there is an influence of Asri park tourism on the economy of the community has a pretty good influence. From the calculation, the tcount is 4,943 while the table is 1,734. Then it was stated that there was an influence of beautiful garden tourism on the economy of the people who were around Line 8 Bridge 3 Air Salek District, Banyuasin Regency
\end{abstract}

Keywords: beautiful garden tourism, community economy

\begin{abstract}
ABSTRAK
Masalah dalam penelitian ini adalah "Apakah ada Pengaruh Wisata Taman Asri Terhadap Perekonomian Masyarakat yang berada di sekitar Jalur 8 Jembatan 3 Kecamatan Air Salek Kabupaten Banyuasin?', Tujuan dalam Penelitian ini adalah untuk menganalisis Pengaruh Wisata Taman Asri Terhadap Perekonomian Masyarakat yang berada di sekitar Jalur 8 Jembatan 3 Kecamatan Air Salek Kabupaten Banyuasin. Metode penelitian ini menggunakan metode Deskriftif Kuantitatif. Populasi dalam penelitian ini adalah masyarakat yang tinggal di sekitar taman asri terdiri dari $129 \mathrm{KK}$, teknik pengambilan sampel menggunakan Claster Sampling (Area Sampling). Teknik pengumpulan data dalam penelitian ini menggunakan angket dengan skala gutman. Analisis yang digunakan dalam penelitian ini menggunakan uji-t. Hasil dari peneitian ini bahwa terdapat pengaruh wisata taman Asri terhadap perekonomian masyarakat mempunyai pengaruh yang cukup baik. Dari perhitungan diperoleh $t_{\text {hitung }}$ sebesar 4,943 sedangkan $t_{\text {tabel }}$ 1,734. Maka dinyatakan ada pengaruh wisata taman asri terhadap perekonomian masyarakat yang berada di sekitar Jalur 8 Jembatan 3 Kecamatan Air Salek Kabupaten Banyuasin
\end{abstract}

Kata kunci : wisata taman asri, perekonomian masyarakat

\begin{tabular}{|l|l|l|l|}
\hline Volume XX & Nomor 2 & September 2019 & e-ISSN : 2580-9199 \\
\hline
\end{tabular}




\section{Pendahuluan}

Indonesia merupakan suatu negara kepulauan yang terdiri dari pulau-pulau, Indonesia merupakan salah satu negara yang terkenal akan keindahan alamnya dimata dunia. Indonesia juga merupakan salah satu negara yang menjadi tujuan destinasi wisata oleh negara lain, banyak potensi objek wisata di Indonesia meliputi objek wisata alam dan wisata sejarah misalnya pengunungan dan laut dengan berbagai keanekaragaman hayati didalamnya. Objek wisata sejarah misalnya candy, monumen dan museum. Pariwisata di Indonesia telah tumbuh dan berkembang hingga sekarang, hal ini tidak lepas dari peran masyarakat dalam meningkatkan sektor pariwisata di daerah tempat tinggal mereka. Namun, masih ada daerah-daerah dengan potensi wisata yang besar kurang maksimal pengelolahanya oleh pemerintah setempat.

Sektor pariwisata merupakan salah satu sektor strategis dalam menggerakkan perekonomian Indonesia dan menjadi bagian dari perekonomian global (Soedarso, Nurif, Windiani. 2014).

Menurut MacDonald dalam Pitana dan Diantara (2009) Pariwisata adalah sebuah mega bisnis. Jutaan orang mengeluarkan terliunan dollar Amerika, meninggalkan rumah dan pekerjaan untuk memuaskan atau membahagiakan diri (pleasure) dan untuk menghabiskan waktu luang (jeisure). Hal ini menjadi bagian penting dalam kehidupan dan gaya hidup di negara-negara maju. Namun demikian memposisikan pariwisata sebagian dari enensial dalam kehidupan sehari-hari merupakan fenomena relatif baru. Pariwisata merupakan suatu proses berpergian sementara oleh seseorang maupun sekelompok orang dengan menuju suatu tempat lain. Dorongan kepergianya adalah karena berbagai kepentingan, baik karena kepentingan ekonomi, sosial, maupun kepentingan lain atau hanya sekedar ingin tahu, atau menambah suatu pengalaman.

Pariwisata berarti perjalanan yang dilakukan dari dari suatu tempat ketempat lain dengan tujuan rekreasi atau bersenangsenang (Banowati, 2014).

Menurut UU No 10 Tahun 2009 Wisata adalah kegiatan perjalanan yang dilakukan oleh seseorang atau sekelompok orang dengan mengunjungi tempat tertentu untuk tujuan rekreasi, pengembangan pribadi, atau mempelajari keunikan daya tarik wisata yang dikunjungi dalam jangka waktu sementara. Pembagunan kepariwisataan dilakukan berdasarkan atas sebagaimana dimaksud dalam pasal 2 yang diwujudkan melalui pelaksanaan 
pembangunan kepariwisataan dengan memperhatikan keanekaragaman, keunikan, dan kekhasan budaya dan alam, serta kebutuhan manusia untuk berwisata.

Pembangunan pariwisata bertujuan agar pariwisata yang ada di Indonesia mampu meningkatkan perekonomian masyarakat sekitar dan dapat memberikan kontribusi ekonomi langsung kepada masyarakat disekitar objek wisata melalui jasa pemandu wisata, fotografer, menyediakan makanan dan minuman, akomodasi, suvenir dan penyediaan jasa transporatasi dan dapat melestarikan lingkungan.

Pengembangan Obyek dan Daya Tarik Wisata (ODTW) yang merupakan penggerak utama sektor kepariwisataan membutuhkan kerjasama seluruh pemangku kepentingan yang terdiri dari masyarakat dan pemerintah, kerjasama langsung dari kalangan usaha maupun dari pihak swasta (Devy dan Soemanto, 2017).

\section{Komponen pengembangan pariwisata}

Diberbagai macam literatur dimuat berbagai macam komponen wisata. Namun ada beberapa komponen wisata yang selalu ada dan merupakan komponen dasar dari wisata. Komponen-komponen tersebut saling berintraksi satu sama lain. Menurut Sudaryana dan Octavia, 2015 Komponenkomponen wisata tersebut dapat dikelompokkan sebagai berikut:

\section{Atraksi dan kegiatan-kegiatan Wisata}

Kegiatan kegiatan wisata yang dimaksud dapat berupa semua hal yang berhubungan dengan lingkungan alami, kebudayaan keunikan suatu daerah dan kegiatan-kegiatan lainya yang berhubungan dengan kegiatan wisata yang menrik wisatawan untuk mengunjungi sebuah objek wisata

\section{Akomodasi}

Akomodasi yang dimaksud adalah berbagai macam hotel dan berbagai jenis fasilitas lain yang berhubungan dengan pelayanan untuk para wisatawan yang berniat untuk bermalam selama wisata yang mereka lakukan.

3. Fasilitas dan pelayanan wisata

Fasilitas dan pelayanan wisata yang dimaksud adalah semua fasilitas yang dibutuhkan dalam perencanaan kawasan wisata

\section{Fasilitas dan Pelayanan Transportasi}

Meliputi trasportasi akses dari dan menuju kawasan wisata, transportasi internal yang berhubungan atraksi utama kawasan wisata dan kawasan pembagunan, termasuk semua jenis fasilitas dan pelayanan yang berhubungan dengan transportasi darat, air, laut dan udara.

5. Infrastruktur lain

Infrastruktur lain dimaksud adalah penyediaan air bersih, listrik, drainase, 
saluran air kotor, telekomunikasi (seperti telepon, telegram, dan radio)

6. Elemen kelembagaan

Kelembagaan yang dimaksud adalah kelembagaan yang diperlukan untuk membangun dan mengelola kegiatan wisata, termasuk perencanaan tenaga kerja dan program pendidikan dan pelatihan

Menurut Lumintang

Pendapatan adalah jumlah penghasilan yang diterima oleh penduduk atas prestasi kerjanya selama satu priode tertentu, baik harian, mingguan, bulanan maupun tahunan. Kegiatan usaha pada akhirnya akan memperoleh pendapatan berupa uang yang diterima dari penjualan produk yang dikurangi biaya yang telah dikeluarkan

Berdasarkan penggolongannya,

Badan Pusat Statistik (BPS, 2014) membedakan pendapatan menjadi 4 golongan adalah:

1) Golongan pendapatan sangat tinggi, adalah jika pendapatan rata-rata lebih dari Rp. 2.500.000,00 per bulan

2) Golongan pendapatan tinggi adalah jika pendapatan rata-rata antara Rp.2.000.000,00 per bulan

3) Golongan pendapatan sedang adalah jika pendapatan rata-rata antara Rp.1.500.000,00 per bulan.

4) Golongan pendapatan rendah adalah jika pendapatan rata-rata kurang dari Rp.1.500.000,00 per bulan.
Banyuasin merupakan salah satu Kabupaten yang ada di Provinsi Sumatera Selatan. Daerah Banyuasin merupakan daerah yang bisa dibilang kurang kepariwisataanya. Kabupaten Banyuasin merupakan salah satu tempat transmigrasi. Di Kecamatan Air Salek ada salah satu objek wisata yaitu taman Asri yang terletak di Desa Salek mukti Jalur 8 Jembatan 3 Kecamatan Air Salek merupakan salah satu 19 Kecamatan yang berada di wilayah Kabupaten Banyuasin, Provinsi Sumatra Selatan.

Objek wisata taman Asri merupakan objek wisata buatan yang merupakan milik pribadi Bapak Sukemi di Jalur 8 Jembatan 2 Salek. Namun melihat minat masyarakat Banyuasin yang begitu tinggi terhadap kehadiran taman Asri akhirya sejak tahun 2017, taman ini dibuka untuk umum. Saat ini masyarakat umum dapat mengujungi wisata taman Asri yang tak begitu kalah indahnya dengan taman punti kayu yang ada di Palembang.

Berdasarkan dari hasil observasi dilapangan dengan Bapak Sukemi sebagai pemilik objek wisata taman Asri menjelaskan mengenai taman Asri bahwa taman ini memiliki luas daerah \pm 1 hektar dan terdapat objek-objek yang bisa dijadikan sebagai objek tempat berfoto dan tempat bersantai atau hanya sekedar berkeliling di 
sekitar taman Asri dan ada beberapa kantin dan tempat parkir kendaran yang disediakan untuk pengunjung yang datang berkunjung ke taman Asri. Tapi masih sangat disayangkan karena taman Asri baru dibuka jadi fasilitas-fasilitas yang ada di taman Asri belum memadai karena objek wisata tersebut belum dikelola dengan baik masih banyak sarana dan prasarana pendukung yang masih kurang lengkap untuk mendukung objek wisata taman Asri, misalnya dari segi akses jalan menujuh taman Asri masih kurang cukup baik, promosi tentang objek wisata taman Asri pun kurang lancar dan hal tersebutlah tentunya yang harus ditangani secara baik sehingga masyarakat yang berada disekitar taman Asri mampu mendapatkan pendapatan masyarakat yang maksimal dari adanya objek wisata taman Asri.

Berdasarkan dari fakta di atas, taman Asri perlu lagi ditingkatkan pengelolahannya secara menyeluruh agar fasilitas-fasilitas taman Asri terpenuhi sehingga dapat menarik minat wisatawan untuk berkunjung ke taman Asri dan dapat menambah pendapatan masyarakat sekitar. Kehidupan masyarakat yang berada disekitar Jalur 8 Jembatan 3 Kecamatan Air Salek Kabupaten Banyuasin selama ini hanya berdasarkan dari sektor pertanian dan penghasilan masyarakat perbulannya tidak tertentu hanya mengandalkan hasil
pertahun.Adanya objek wisata taman Asri ini tentunya akan menambah pendapatan masyarakat disektor pariwisata seperti bisa menjadi pedagang souvenir atau pedagang makanan dan dapat mengenalkan ciri khas makanan daerah kepada para pengunjung wisatawan yang berasal dari luar Kabupaten Banyuasin sehingga mampu menjadi sumber pendapatan perekonomian. Untuk itu penullis tertarik untuk melakukan penelitan dengan judul "Pengaruh Wisata Taman Asri Terhadap Pereknomian Masyarakat Yang Berada di Jalur 8 Jembatan 3 Kecamatan Air Salek Kabuaten Banyuasin”.

\section{METODOLOGI PENELITIAN}

Metode penelitian yang digunakan dalam penelitian ini adalah metode penelitian deskiptif dengan pendekatan kuantitatif dimana data-data peneliti diolah untuk menghasilkan suatu hubungan kausalitas antara variabel indenpenden dan variabel denpenden. Untuk menjelaskan hubungan kausalitas ini, penulis harus menuliskan kontrol dan pengukuran yang sangat cermat terhadap variabel-variabel penelitinya.

Populasi dalam penelitian ini adalah masyarakat Jalur 8 Jembatan 3 yang berada disekitar Taman Asri. Teknik pengambilan sampel menggunakan teknik Cluster Sampling. Teknik pengumpulan data dalam penelitian ini menggunakan angket dan 
dokumentasi. Sedangkan teknik analisis data menggunakan uji-t .

\section{HASIL DAN PEMBAHASAN}

Tabel 21 (Distribusi Frekunsi)

\begin{tabular}{|c|c|c|c|c|c|}
\hline Responden & $\mathbf{X}$ & $\mathbf{Y}$ & X.Y & $X^{2}$ & $Y^{2}$ \\
\hline 1. & 2 & 8 & 16 & 4 & 64 \\
\hline 2. & 3 & 8 & 24 & 9 & 64 \\
\hline 3. & 2 & 8 & 16 & 4 & 64 \\
\hline 4. & 2 & 8 & 16 & 4 & 64 \\
\hline 5. & 2 & 8 & 16 & 4 & 64 \\
\hline 6. & 3 & 8 & 24 & 9 & 64 \\
\hline 7. & 2 & 8 & 16 & 4 & 64 \\
\hline 8. & 2 & 7 & 14 & 4 & 49 \\
\hline 9. & 2 & 8 & 16 & 4 & 64 \\
\hline 10. & 2 & 8 & 16 & 4 & 64 \\
\hline 11. & 3 & 8 & 24 & 9 & 64 \\
\hline 12. & 2 & 7 & 14 & 4 & 49 \\
\hline 13. & 2 & 8 & 16 & 4 & 64 \\
\hline 14. & 2 & 8 & 16 & 4 & 64 \\
\hline 15. & 2 & 8 & 16 & 4 & 64 \\
\hline 16. & 2 & 8 & 16 & 4 & 64 \\
\hline 17. & 2 & 7 & 14 & 4 & 49 \\
\hline 18. & 2 & 8 & 16 & 4 & 64 \\
\hline 19. & 2 & 8 & 16 & 4 & 64 \\
\hline 20. & 2 & 8 & 16 & 4 & 64 \\
\hline Jumlah & 43 & 160 & 338 & 68 & 1235 \\
\hline
\end{tabular}

(Sumber: Olah data, 2018)

Tabel diatas merupakan tabel pengelolahan data ( tabel kerja ) untuk mencari angka indeks korelasi ( ' $\mathrm{r}$ '"). Tabel diatas terdiri dari 6 kolom pertama menujukan banyaknya responden yaitu 20 responden, kolom kedua menujukan $\mathrm{X}$, dan kolom ketiga menujukan $\mathrm{Y}$, kolom keempat menunjukan perkalian antara $\mathrm{X}$ dan $\mathrm{Y}$, kolom kelima menujukan pengkuadratan X ( ), kolom keenam menujukan pengkuadratan Y ( ). $\quad Y^{2}$ diatasdiperoleh data masing-masing sebagai berikut:

Jumlah X
Jumlah Y $=160$

Jumlah perkalian X dan Y (X.Y) $=338$

Jumlah pengkuadratan $\mathrm{X}\left(X^{2}\right) \quad=68$

Jumlah pengkuadratan $\mathrm{Y}\left(Y^{2}\right) \quad=1235$

Setelah keseluruhan data dihitung dan disajikan didalam tabel, maka dapat dicari koenfisien korelasinya dengan cara sebagai berikut:

$$
\begin{aligned}
= & \frac{N \sum X Y-\left(\sum X\right)\left(\sum Y\right)}{\sqrt{\left\{N \sum X^{2-}\left(\sum X\right)^{2}\right\}}\left\{N \sum Y^{2-}\left(\sum Y\right)^{2}\right\}} \\
r x y & \frac{20 x 338-43 X 160}{\sqrt{\left(D x \times 68-(43)^{2} \times\left(20 x-(160)^{2}\right.\right.}} \\
& =\frac{6,80-6,780}{\sqrt{(1,960-1,849) x(3700-25600)}} \\
& =\frac{80}{\sqrt{11100}} \\
& =\frac{80}{105, \mathbf{5 6}} \\
& =0,759
\end{aligned}
$$

\section{Uji ''t',}

Untuk menguji signifikasi hubungan digunakan rumus uji ' $t$ '” sebagai berikut:

$$
\begin{aligned}
& t=\frac{\sqrt[r]{n-2}}{\sqrt{1-r^{2}}} \\
& t=\frac{0,759 \sqrt{20-2}}{1-(0,759)^{2}} \\
& t=\frac{0,759, \sqrt{18}}{\sqrt{(1-0,576081)}}
\end{aligned}
$$

$$
t=\frac{0,759 \times 4,24}{\sqrt{0,423919}}
$$$$
t=\frac{3,218}{0,651}
$$$$
t=4,943
$$

$t_{\text {hitung }}=4,943$ 
Harga $t_{\text {hitung }}$ tersebut

selanjutnya dibandingkan dengan harga

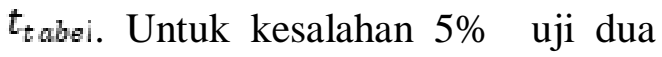
pihak dan $\mathrm{dk}=\mathrm{n}-2=20$, maka diperoleh

$t_{\text {tabei }}=1,734$. Dari perhitungan nilai diatas diperoleh $\quad \alpha_{0,05} \quad t_{\text {hitung }}=$ 4,943 sedangka $\quad t_{\text {tabei }}{ }^{\mathrm{p}} 0,05=2$, maka $t_{\text {hitung }}>\quad t_{\text {tabei sehingga hipotesis }}$ alternatif (Ha) yang menyatakan "ada pengaruh wisata taman asri terhadap perekonomian masyarakat yang berada di sekitar Jalur 8 Jembatan 3 Kecamatan Air Salek Kabupaten Banyuasin diterima. Ini berarti hipotesis nol (Ho) yang menyatakan (tidak ada pengaruh wisata taman Asri terhadap perekonomian masyarakat yang berada di sekitar Jalur 8 Jembatan 3 Kecamatan Air Salek Kabupaten Banyuasin ditolak.

Dalam penelitian ini penulis telah melakukan survei, dan penulis turun langsung membagikan 20 angket kepada masyarakat sekitar objek wisata taman Asri, untuk mengetahui apakah ada pengaruh objek wisata taman Asri terhadap pendapatan masyarakat sekitar Desa Saleh mukti. Kabupaten Banyuasin merupakan sebuah kota kecil yang mempunyai potensi yang bisa dikembangkan salah satunya wisata taman Asri, selain memiliki peranan sebagai tempat objek wisata ini juga diharapakan dapat membantu pendapatan masyarakat sekitar.

Dari pendeskripsian pengambilan data dapat diketahui bahwa pendapatan masyarakat di Desa Saleh Mukti selalu menurun dan meningkat karena di pengaruhi oleh banyaknya jumlah pengunjug yang berkunjung ke objek wisata taman Asri yang menyebabakan turun naiknya pendapatan masyarakat. Berdasarkan hasil penelitian yang dilaksanakan, maka peneliti dapat menyimpulkan bahwa faktor yang mempengaruhi pendapatan masyarakat yaitu dari banyaknya wistawan yang berkunjung ke objek wistaa taman Asri, jika semakin banyak pengunjung yang datang maka akan menambah pedapatan masyrakat sekitar dan jika wisatawan yang berkunjung lebih sedikit maka akan berpengaruh pada pendapatan masyarakat sekitar akan menurun. Angket yang telah disebarkan lalu dianalisis dan diolah melalui penghitungan dan interpertasi terhadap data-data yang diperoleh dengan menginput data Variabel $\mathrm{X}$ dan Variabel Y kedalaman 3 kolom, kolom pertama menunjukan banyaknya 20 responden, kolom kedua menujukan banyaknya item soal yaitu beberapa banyak soal yang tersedia, dan kolom ketiga menujukan jumlah skor dari masing-masing item soal.

Selanjutnya mengelola atau melakukan perhitungan Data Variabel X dan 
Variabel Y untuk mencari angka indeks korelasinya yang terdiri dari 6 kolom, kolom pertama menujukan banyaknya responden yaitu 20 responden, kedua menujukan $\mathrm{X}$ dengan jumlah (43), kolom ketiga menujukan Y (160), kolom keempat menujukan perkalian antara $\mathrm{X}$ dan $\mathrm{Y}$ dengan jumblah (338), kolom kelima menujuka pengkuadratan $\mathrm{X}\left(\mathrm{X}^{2)}\right.$ dengan jumlah (68), kolom keenam menujukan pengkuadratan $\mathrm{Y}$ $\left(\mathrm{Y}^{2}\right)$ dengan jumlah (1235). Setelah keseluruhan data dihitung dan disajikan dalam tabel, maka koenfesien korelasinya yaitu $=0,759$. perhitungan pengaruh objek wisata taman Asri terhdap perekonomian masyarakat adalah sebesar 57\% maka untuk penarikan kesimpulan tentang pengaruh objek wisata taman Asri terhadap perekonomian masyarakat di Jalur 8 Jembatan 3 Kecamatan Air Salek Kabupaten Banyuasi sudah cukup signitifikan.

\section{KESIMPULAN}

Berdasarkan dari hasil penelitian bahwa pengaruh wisata taman Asri terhadap perekonomian masyarakat mempunyai pengaruh yang cukup baik. . Dari analisis diatas setelah keseluruhan data dihitung dan disajikan dalam tabel, maka kontribusi variabel $\mathrm{X}$ terhadap variabel $\mathrm{Y}$ yaitu sebesar 0,759. Hal tersebut menunjukan wisata taman Asri sangat berpengaruh terhadap perekonomian masyarakat. Dimana terdapat dampak positip ekonomi bagi masyarakat desa Saleh Mukti menjadi income bagi warga setempat, sedangkan dampak negatifnya kependudukan di Desa Saleh Mukti menjadi ramai dan padat.

Hasil analisis data diperoleh $0,05=$ 4,943 sedangkan ${ }^{\mathrm{v}} 0,05=1,734$ maka > sehingga hipotesis alternatif (Ha) yang menyatakan "ada pengaruh wisata taman Asri terhadap perekonomian masyarakat yang berada di sekitar Jalur 8 Jembatan 3 Kecamatan Air Salek Kabupaten Banyuasin diterima. Ini berarti hipotesis nol (Ho) yang menyatakan (tidak ada pengaruh wisata taman Asri terhadap perekonomian masyarakat yang berada di sekitar Jalur 8 Jembatan 3 Kecamatan Air Salek Kabupaten Banyuasin ditolak.

\section{Daftar Pustaka}

Devy, Helln Angga., 2017. Pengembangan Objek dan Daya Tarik Wisata Alam Sebagai Daerah Tujuan Wisata Di Kabupaten Karanganyar. Jurnal Sosiologi DILEMA, 32 (1). 34-44.

Soedarso., Nurif, Muchammad., Windiani., 2014. Potensi dan kendala pengembangan pariwisata berbasis kekayaan alam dengan pendekatan marketing place (Studi Kasus Pengembangan pariwisata di kabupaten 
Bojonegoro). Jurnal Sosial Humaniora.

Volume 7 No 2 November 2014.

Banowati,Eva, 2014.Geografi Indonesia.

Yogyakarta: Ombak

Badan Pusat Statistik (BPS) Pendapatan, www.bps.go.id/2008

Lumintang, Fatmawati M. Analisis

Pendapatan Petani di Desa TEEP

Kecamatan Lagowan Timur. Jurnal

Riset Ekonomi, Manajemen, Bisnis dan

Akuntansi. Vol 1 No 3 September 2013.

Undang-Undang Republik Indonesia Nomor

10 Tahun 2009 tentang kepariwisataan.

Pitana, I Gede dan I Ketut Surya Diantara.

2009. Pengantar ilmu

pariwisata.Jogjakarta: Andi

Suryadana, Liga dan Vanny Octavia.2015.

Pengantar pemasaran pariwisata.

Bandung: Alfabeta. 